\title{
Analisis Faktor yang Mempengaruhi Ketepatan Waktu Pelaporan Keuangan pada Perusahaan Consumer Goods Terdaftar di Bursa Efek Indonesia Periode 2016-2018
}

\author{
Hasdi Suryadi \\ STIE Pancasetia Banjarmasin \\ Jl. A. Yani Km. 5.5 Banjarmasin Kalimantan Selatan \\ E-mail: hasdisuryadi@yahoo.com
}

\begin{abstract}
This study aims to test empirically the independent variables consisting of profitability, company size, company age, auditor opinion, ownership structure and leverage affect the dependent variable on timeliness of financial reporting partially and simultaneously. The data population used is all consumer goods companies listed on the Indonesia Stock Exchange for the period 2016-2018. This research uses purposive sampling method, there are 24 companies that meet the criteria with a total of 72 samples used as research data. Data analysis using logistic regression analysis. The results showed that partially profitability, company size, company age, auditor opinion, ownership structure and leverage had no effect on the timeliness of financial reporting and simultaneously profitability, company size, company age, auditor opinion, ownership structure and leverage had an effect on timeliness finance report.
\end{abstract}

Keywords: Timeliness, Profitability, Company Size, Company Age, Auditor Opinion, Ownership structure, Leverage

Abstrak

Penelitian ini bertujuan untuk menguji secara empiris variabel independen yang terdiri dari profitabilitas, ukuran perusahaan, umur perusahaan, opini auditor, struktur kepemilikan dan leverage mempengaruhi variabel dependen ketepatan waktu pelaporan keuangan secara parsial dan simultan. Populasi data yang digunakan adalah seluruh perusahaan consumer goods yang terdaftar di Bursa Efek Indonesia periode 2016-2018. Penelitian ini menggunakan metode purposive sampling, ada 24 perusahaan yang memenuhi kriteria dengan total 72 sampel yang digunakan sebagai data penelitian. Analisis data menggunakan analisis regresi logistik. Hasil penelitian menunjukkan bahwa secara parsial profitabilitas, ukuran perusahaan, umur perusahaan, opini auditor, struktur kepemilikan dan leverage tidak berpengaruh terhadap ketepatan waktu pelaporan keuangan dan secara simultan profitabilitas, ukuran perusahaan, umur perusahaan, opini auditor, struktur kepemilikan dan leverage berpengaruh terhadap ketepatan waktu pelaporan keuangan.

Kata kunci: Ketepatan Waktu, Profitabilitas, Ukuran Perusahaan, Umur Perusahaan, Opini Auditor, Struktur Kepemilikan, Leverage

(C) 2021 Jurnal Riset Inspirasi Manajemen dan Kewirausahaan

\section{PENDAHULUAN}

Perkembangan pasar modal saat ini telah meningkat dengan pesat dan tentunya di masa mendatang bisnis investasi ini akan menjadi sedemikian kompleks, terutama dalam upaya penyediaan dan perolehan informasi dalam setiap pembuatan keputusan. Salah satu sumber informasi penting dalam bisnis investasi di pasar modal adalah laporan keuangan yang disediakan setiap perusahaan yang Go Public.

Laporan keuangan merupakan alat bagi perusahaan untuk menguji dan menganalisis kondisi keuangan perusahaan yang memuat catatan-catatan mengenai kegiatan bisnis sebuah entitas dalam suatu periode tertentu. Laporan keuangan dapat digunakan oleh investor, kreditor, dan pemasok dalam pengambilan keputusan. Ketepatan waktu pelaporan keuangan merupakan suatu karakteristik yang penting bagi suatu laporan keuangan. Untuk pihak manajemen sendiri, laporan keuangan dapat dijadikan sebagai bahan pertimbangan bagi manajemen perusahaan dalam menetapkan rencana kegiatan perusahaan untuk periode yang akan datang.

Ketepatan waktu (Timeliness) merupakan salah satu faktor yang penting didalam menyajikan informasi yang relevan. Laporan keuangan akan 
dikatakan bermanfaat apabila informasi tersebut disediakan tepat waktu bagi pembuat keputusan sebelum informasi tersebut kehilangan kemampuannya dalam mempengaruhi pengambilan keputusan. Jika dalam pelaporan terdapat penundaan yang tidak seharusnya, maka informasi yang dihasilkan akan kehilangan relevansinya. Kebutuhan akan ketepatan waktu pelaporan keuangan telah disebutkan secara jelas dalam kerangka dasar penyusunan penyajian laporan keuangan, bahwa ketepatan waktu merupakan salah satu karakteristik yang harus dipenuhi agar laporan keuangan yang disajikan relevan untuk membuat keputusan.

Nilai dari suatu ketepatan waktu pelaporan keuangan sangat penting bagi tingkat pemanfaatan laporan tersebut. Apabila laporan keuangan tersebut tidak disampaikan dengan tepat waktu, maka akan mengurangi manfaat dari laporan keuangan. Pengguna laporan keuangan sangat membutuhkan informasi ketepatan waktu agar segera melakukan analisis dan membuat keputusan mengenai modal yang sudah, atau akan diinvestasikan pada perusahaan.

Fenomena mengenai ketepatan waktu pelaporan keuangan yang terdapat di Bursa Efek Indonesia (BEI) mencatat baru 578 perusahaan tercatat yang menyampaikan laporan keuangan semester I-2019 tepat waktu. Hingga saat ini, total perusahaan tercatat di BEI adalah 737 perusahaan. Hal ini berarti baru $78,4 \%$ dari total emiten yang melaporkan keuangan semester I-2019 tepat waktu. Berdasarkan penjelasan diatas, masih ada perusahaan yang terlambat pada saat menyampaikan laporan keuangan tersebut. Beberapa dari perusahaan yang terlambat menyampaikan laporan keuangan memiliki suatu alasan khusus yang menyebabkan tertundanya perilisan laporan keuangan tersebut. Apabila perusahaan tersebut tidak memiliki suatu alasan, perusahaan akan dikenakan sanksi oleh Bursa Efek Indonesia (BEI) (www.kontan.co.id).

Agency Theory berkaitan erat terhadap informasi keuangan yang apabila disampaikan tepat waktu sangat bermanfaat bagi pemakainya. Ketepatan waktu pelaporan keuangan memiliki nilai yang penting terhadap kemanfaatan suatu laporan. Sebaliknya, apabila laporan tersebut tidak disampaikan dengan tepat waktu akan mengurangi manfaat dari laporan tersebut. Informasi yang tidak disampaikan dengan tepat waktu akan menyebabkan nilai dari informasi tersebut berkurang dalam pengambilan keputusan.

Perusahaan go public yang telah terdaftar di Bursa Efek Indonesia berkewajiban untuk mempublikasikan laporan keuangan secara berkala yang disusun berdasarkan standar akuntansi keuangan dan telah diaudit oleh akuntan publik. Penyampaian laporan keuangan bagi perusahaan publik diatur dalam peraturan yang dikeluarkan oleh OJK (Otoritas Jasa Keuangan) yaitu peraturan Nomor: 29/POJK.04/2016 tentang penyampaian laporan keuangan tahunan emiten dan perusahaan. Peraturan tersebut menyebutkan bahwa perusahaan publik yang pernyataan pendaftarannya telah menjadi efektif wajib menyampaikan laporan tahunan kepada OJK (otoritas jasa keuangan) paling lama akhir bulan ke 4 setelah tahun buku berakhir OJK, 2016. Keterlambatan pelaporan keuangan masih terjadi dapat dihitung tanggal publikasinya ke BEI, keterlambatan pelaporan keuangan ini dapat mempengaruhi informasi yang dipublikasikan, sehingga akan berpengaruh terhadap ketidakpastian keputusan berdasarkan informasi yang tidak relevan lagi.

Menurut Yadika (2019) pada pemaparan oleh Managing Director Jagartha Advisors mengatakan bahwa setidaknya ada dua sektor saham yang diperkirakan layak beli oleh investor pada tahun 2019. Dua sektor saham tersebut ialah industri barang konsumsi (consumer goods) serta telekomunikasi. Secara umum dua sektor utama tersebut akan mendapatkan dampak positif secara langsung dari hajatan politik pada 2019. Terlihat dari upaya pemerintah untuk meningkatkan kembali daya beli masyarakat melalui social spending dan juga subsidi BBM yang tidak dikurangi. Penelitian ini menggunakan objek perusahaan Consumer Goods yang terdaftar di Bursa Efek Indonesia periode 20162018. Alasan memilih sektor industri consumer goods karena produk-produk dari perusahaan ini sendiri merupakan suatu kebutuhan sehari-hari yang diperlukan oleh masyarakat. Perusahaan ini juga merupakan salah satu sektor perusahaan yang mempunyai prospek bagus dan tahan terhadap krisis. Adapun alasan dalam menambahkan variabel struktur kepemilikan yaitu struktur kepemilikan mempunyai andil besar dalam pendelegasian wewenang dan tanggung jawab internal perusahaan, yang dalam penelitian ini menggunakan kepemilikan pihak luar yang mempunyai kekuatan besar untuk menekan manajemen dalam menyajikan laporan keuangan tepat waktu, karena ketepatan waktu pelaporan keuangan akan mempengaruhi pengambilan keputusan ekonomi (Juwita, 2010). Serta alasan dalam menambahkan variabel leverage yaitu sebagai salah satu parameter untuk mengukur kesehatan keuangan perusahaan, rasio leverage dibutuhkan untuk membantu manajemen dan investor dalam memahami tingkat struktur modal pada perusahaan terkait. Selain itu, rasio ini juga mencerminkan sumber pembiayaan dalam operasional bisnis atau kegiatan bisnis perusahaan, dari utang ataukah ekuitas.

\section{LANDASAN TEORI}

\section{Teori Keagenan (Agency Theory)}

Agency theory berkaitan erat terhadap informasi keuangan yang apabila disampaikan tepat waktu sangat bermanfaat bagi pemakainya. Ketepatan waktu pelaporan keuangan memiliki nilai yang penting terhadap kemanfaatan suatu laporan. 
Sebaliknya, apabila laporan tersebut tidak disampaikan dengan tepat waktu akan mengurangi manfaat dari laporan tersebut. Informasi yang tidak disampaikan dengan tepat waktu akan menyebabkan nilai dari informasi tersebut berkurang dalam pengambilan keputusan. Teori keagenan merupakan suatu gambaran hubungan antara pemegang saham (principal) dengan pihak manajemen perusahaan (agent). Teori ini muncul sebagai bentuk pertanggungjawaban pihak manajemen yang dikontrak oleh pemegang saham untuk bekerja demi kepentingan pemegang saham (Dwiyanti, 2010).

\section{Teori Signal (Signalling Theory)}

Teori signal (signalling theory) menekankan kepada pentingnya informasi yang dikeluarkan oleh perusahaan terhadap keputusan investasi pihak luar perusahaan. Informasi yang diberikan oleh perusahaan akan direspon oleh pihak luar perusahaan sebagai sinyal good news atau bad news sehingga pihak luar dapat membedakan perusahaan yang berkualitas baik dan buruk.

Signalling theory dan asymmetric informations digagas pertama kali oleh Ackerlof, Spence, dan Stigliz yang menjadikan mereka memperoleh Nobel Ekonomi pada tahun 2001. Signalling theory dikembangkan dalam ilmu ekonomi dan keuangan yang menggunakan informasi yang asimetris antara perusahaan dengan pihak luar karena manajemen lebih banyak tahu tentang prospek perusahaan dan peluang masa depan dibandingkan pihak luar (investor). Asimetri informasi akan terjadi jika manajemen tidak secara penuh menyampaikan semua informasi yang dapat mempengaruhi nilai perusahaan ke pasar modal. Untuk menghindari asimetris informasi, perusahaan harus memberikan informasi sebagai sinyal kepada investor. Asimetri informasi perlu diminimalkan, sehingga perusahaan go public dapat menginformasikan keadaan perusahaan secara transparan kepada investor (Dwiyanti, 2010).

\section{Laporan Keuangan}

Laporan keuangan merupakan alat informasi bagi suatu perusahaan dalam menentukan posisi keuangan. Laporan keuangan memiliki kegunaan dalam memberikan gambaran atau menilai presentasi yang telah dicapai oleh perusahaan selama periode tertentu kepada pihak-pihak yang berkepentingan didalam perusahaan. Akuntansi keuangan memiliki tujuan khusus yaitu menghitung dan melaporkan informasi keuangan untuk para pemangku kepentingan (stakeholders) suatu entitas: persero/pemegang saham, calon persero/pemegang saham, kreditur, calon kreditur, serikat pekerja, badan pemerintah, manajemen, dan lain-lain (Kartikahadi, 2012).
Menurut Kasmir (2015:6-10) laporan keuangan yang disajikan perusahaan sangat penting bagi manajemen dan pemilik perusahaan. Di samping itu, banyak pihak yang memerlukan dan berkepentingan terhadap laporan keuangan yang dibuat perusahaan, seperti pemerintah, kreditor, investor, maupun para supplier. Laporan keuangan menggambarkan pos-pos keuangan perusahaan yang diperoleh dalam suatu periode.

\section{Ketepatan Waktu Pelaporan Keuangan}

Ketepatan waktu pelaporan keuangan merupakan batasan penting pada publikasi laporan keuangan. Informasi akuntansi harus dilakukan secepat mungkin untuk menjamin tersedianya informasi sekarang di tangan pemakai. Informasi yang relevan akan bermanfaat bagi para pemakai apabila tersedia tepat waktu sebelum pemakai kehilangan kemampuan untuk mempengaruhi keputusan yang akan diambil.

Menurut pernyataan Standar Akuntansi Keuangan (IAI, 2016) dalam Sari (2019) bahwa tujuan laporan keuangan adalah menyediakan informasi yang menyangkut posisi keuangan, kinerja, serta perubahan posisi keuangan suatu perusahaan yang bermanfaat bagi sejumlah besar pengguna dalam pengambilan keputusan ekonomi. Ketepatan waktu tidak menjamin relevansi, tetapi relevansi informasi tidak dimungkinkan tanpa ketepatan waktu. Informasi mengenai kondisi dan posisi perusahaan harus secara cepat dan tepat waktu sampai ke pemakai laporan keuangan. Ketepatan waktu menunjukkan rentang waktu antara penyajian informasi yang diinginkan dan frekuensi informasi pelaporan. Apabila informasi tersebut tidak disampaikan dengan tepat waktu akan menyebabkan informasi tersebut kehilangan nilai didalam memengaruhi kualitas keputusan (Prahesty, 2011).

\section{Faktor-Faktor yang Mempengaruhi Ketepatan Waktu Pelaporan Keuangan}

Penelitianini, penulis akan mengajukan 5 faktor yang mempengaruhi ketepatan waktu pelaporan keuangan perusahaan, yaitu: profitabilitas, ukuran perusahaan, umur perusahaan, opini auditor, dan struktur kepemilikan.

1. Profitabilitas

Profitabilitas merupakan gambaran dari kinerja manajemen dalam mengelola perusahaan. Ukuran profitabilitas dapat berbagai macam seperti: laba operasi, laba bersih, tingkat pengembalian investasi/aktiva, dan tingkat pengembalian ekuitas pemilik. Lebih lanjut, Kasmir (2018:196) rasio profitabilitas merupakan rasio untuk menilai kemampuan perusahaan dalam mencari keuntungan hal ini 
ditunjukkan oleh laba yang dihasilkan dari penjualan dan pendapatan investasi. Perusahaan yang memiliki profitabilitas tinggi dapat dikatakan bahwa laporan keuangan perusahaan tersebut mengandung berita baik dan perusahaan yang mengalami berita baik akan cenderung menyerahkan laporan keuangannya tepat waktu. Hal ini juga berlaku jika profitabilitas perusahaan rendah dimana hal ini mengandung berita buruk, sehingga perusahaan cenderung tidak tepat waktu menyerahkan laporan keuangannya (Yunita, 2017).

2. Ukuran Perusahaan (Size)

Ukuran suatu perusahaan merupakan hal yang perlu diperhatikan terutama bagi para investor dan juga kreditor. Ukuran perusahaan merupakan aset yang terdiri dari biaya-biaya yang dapat diperkirakan akan memberikan manfaat ekonomi di masa yang akan datang (Herry, 2012:68). Lebih lanjut, menurut Sugiarto (2009:121) ukuran perusahaan merupakan proksi bagi informasi asimetri antara perusahaan dengan pasar. Ukuran perusahaan memiliki dua peran yaitu mempunyai dampak yang berbeda pada pengambilan keputusan perusahaan mengenai pendanaan. Peran kedua dalam ukuran perusahaan yang besar akan sulit mengalami kebangkrutan.

Ukuran perusahaan dapat dinilai dari beberapa segi, besar kecilnya ukuran perusahaan dapat didasarkan pada total nilai aktiva, total penjualan, kapitalisasi pasar, jumlah tenaga kerja dan sebagainya. Semakin besar nilai itemitem tersebut maka akan semakin besar pula ukuran perusahaan itu (Imaniar, 2016).

3. Umur Perusahaan (Age)

Umur perusahaan dapat diukur dari lamanya suatu perusahaan berdiri, berkembang dan juga dapat bertahan. Perusahaan yang sudah lama berdiri memiliki pengalaman yang cukup dalam menjalankan perusahaan tersebut dan memiliki kinerja yang baik sehingga mendapat kepercayaan dari masyarakat. Semakin lama umur suatu perusahaan maka kemampuan untuk menyelesaikan berbagai kendala bisnis perusahaan akan dapat terlewati dengan lancar tanpa menghambat kinerja perusahaan tersebut. Umur perusahaan merupakan hal yang dipertimbangkan investor dalam menanamkan modalnya. Jika perusahaan telah lama berdiri biasanya dianggap memiliki kinerja yang baik sehingga menimbulkan kepercayaan masyarakat. Perusahaan yang telah lama berdiri, secara tidak langsung membuktikan bahwa perusahaan mampu bertahan dan meraih laba dalam kondisi ekonomi yang tidak stabil. Selain itu, perusahaan juga mampu mempertahankan reputasi maupun posisi dalam industri dalam suatu persaingan yang semakin ketat (Imaniar, 2016).

4. Opini Auditor

Opini audit adalah pendapat akuntan publik atau auditor independen atas laporan keuangan tahunan perusahaan yang telah diauditnya. Auditor sebagai pihak yang independen di dalam mengaudit laporan keuangan suatu perusahaan publik memberikan opini atas laporan keuangan yang diauditnya. Opini audit yang diberikan oleh auditor independen melalui beberapa tahap audit yang dilakukan dapat memberi simpulan atas laporan keuangan yang diauditnya (Suryanto dan Pahala, 2016). Menurut Agoes (2012:74) menyatakan bahwa 'lembaran opini merupakan tanggung jawab akuntan publik, dimana akuntan publik memberikan pendapatnya terhadap kewajaran laporan keuangan yang disusun oleh manajemen dan merupakan tanggung jawab manajemen'.

Opini auditor bertujuan untuk memberikan pendapat mengenai kewajaran suatu laporan keuangan yang dibuat oleh manajemen perusahaan. Dalam mengaudit laporan keuangan, objeknya meliputi laporan keuangan antara lain adalah Neraca, Laporan Laba/Rugi, Laporan Perubahan Posisi Keuangan dan Laporan Arus Kas. Kehadiran pihak independen di luar perusahaan diperlukan untuk membuktikan kewajaran laporan keuangan yang disajikan oleh manajemen, sehingga laporan keuangan akan lebih dipercaya oleh para pemakainya, dalam rangka meningkatkan keandalan laporan keuangan dibutuhkan peran utama dari auditor independen (Putri, 2018).

5. Struktur Kepemilikan

Struktur kepemilikan merupakan poin penting untuk mengontrol masalah manajemen perusahaan melalui pemilihan agen atau dewan perusahaan untuk melakukan pengelolaan dan pengawasan perusahaan. Struktur kepemilikan juga mempunyai andil besar dalam pendelegasian wewenang dan tanggung jawab internal perusahaan. Terdapat dua aspek kepemilikan yang perlu dipertimbangkan yaitu: kepemilikan oleh pihak luar dan kepemilikan oleh pihak dalam. Pemilik dari pihak luar dianggap berbeda dengan pihak manajemen, dimana kecil kemungkinannya pemilik dari pihak luar untuk terlibat dengan urusan bisnis perusahaan sehari-hari. Pemilik perusahaan dari pihak luar mempunyai kekuatan yang besar untuk menekan manajemen dalam menyajikan laporan keuangan tepat waktu, karena ketepatan waktu pelaporan keuangan akan mempengaruhi pengambilan keputusan ekonomi (Juwita, 2010). Kepemilikan perusahaan oleh pihak luar mempunyai kekuatan yang besar dalam mempengaruhi perusahaan melalui media massa berupa kritikan atau komentar yang semuanya 
dianggap suara publik atau masyarakat. Adanya konsentrasi kepemilikan pihak luar menimbulkan pengaruh dari pihak luar sehingga mengubah pengelolaan perusahaan yang semula berjalan sesuai keinginan perusahaan itu sendiri menjadi memiliki keterbatasan (Choiruddin, 2015).

6. Leverage

Leverage ratio atau yang lebih akrab disebut dengan rasio leverage adalah rasio keuangan yang menunjukkan tingkat utang yang telah dikeluarkan oleh suatu badan usaha atau bisnis. Rasio leverage disebut juga dengan istilah rasio solvabilitas dapat dipahami sebagai rasio keuangan yang mengukur kemampuan suatu perusahaan untuk memenuhi kewajiban atau utang jangka panjangnya. Utang jangka panjang itu sendiri dimaknai sebagai kewajiban atau utang yang waktu jatuh temponya lebih dari satu tahun.

Rasio leverage membandingkan antara total beban utang perusahaan terhadap aset atau ekuitasnya. Artinya, rasio ini menunjukkan seberapa banyak aset perusahaan yang dimiliki oleh para pemegang saham dibandingkan dengan aset yang dimiliki oleh para kreditur atau pemberi utangnya. Suatu perusahaan dikatakan memiliki tingkat leverage yang tinggi, apabila jumlah aset yang dimiliki perusahaan lebih sedikit dibandingkan dengan jumlah aset krediturnya.

Sebagai salah satu parameter untuk mengukur kesehatan keuangan perusahaan, rasio leverage dibutuhkan untuk membantu manajemen dan investor dalam memahami tingkat struktur modal pada perusahaan terkait. Selain itu, rasio ini juga mencerminkan sumber pembiayaan dalam operasional bisnis atau kegiatan bisnis perusahaan, dari utang ataukah ekuitas.

\section{Kerangka Pemikiran}

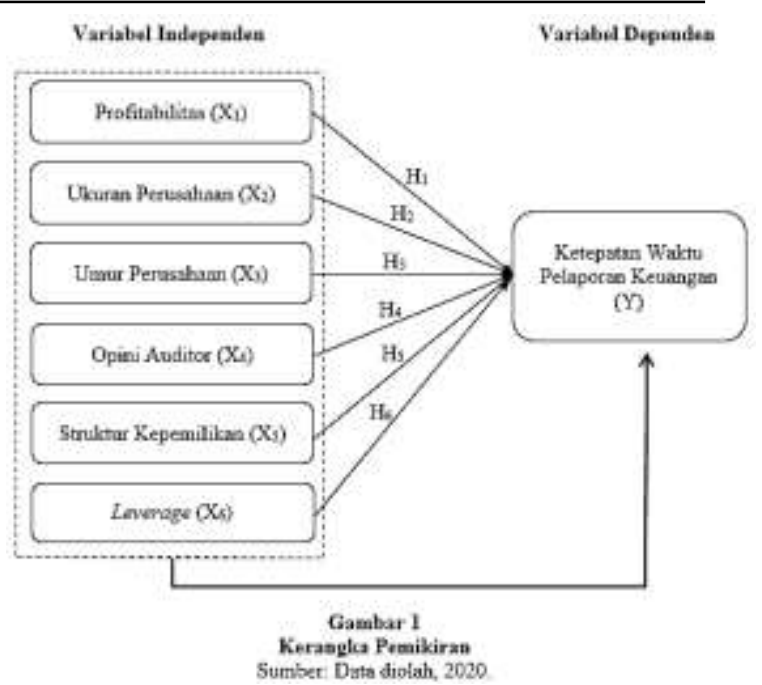

Berdasarkan kerangka berfikir diatas, hipotesis dalam penelitian dirumuskan sebagai berikut:

H1 : Profitabilitas berpengaruh positif terhadap ketepatan waktu pelaporan keuangan.

$\mathrm{H} 2$ : Ukuran Perusahaan berpengaruh positif terhadap ketepatan waktu pelaporan keuangan.

H3 : Umur perusahaan berpengaruh positif terhadap ketepatan waktu pelaporan keuangan.

$\mathrm{H}_{4}$ : Opini auditor berpengaruh positif terhadap ketepatan waktu pelaporan keuangan.

H5 : Struktur kepemilikan berpengaruh positif terhadap ketepatan waktu pelaporan keuangan.

H6 : Leverage berpengaruh positif terhadap ketepatan waktu pelaporan keuangan.

\section{METODE PENELITIAN}

\section{Jenis dan Sumber Data}

Jenis data yang digunakan dalam penelitian ini adalah data sekunder yang berupa laporan keuangan perusahaan consumer goods yang terdaftar di Bursa Efek Indonesia periode 2016-2018. Sumber data yang digunakan dalam penelitian ini diperoleh melalui website dengan cara mengunduh laporan keuangan melalui situs www.idx.co.id.

\section{Populasi dan Teknik Pengambilan Sampel}

Populasi dalam penelitian ini adalah seluruh perusahaan consumer goods yang terdaftar di Bursa Efek Indonesia periode 2016-2018. Sampel yang digunakan dalam penelitian ini menggunakan metode purposive sampling dengan kriteria:

1. Perusahaan Consumer Goods yang terdaftar di Bursa Efek Indonesia periode 2016-2018.

2. Perusahaan yang menerbitkan laporan keuangan selama periode 2016-2018 berturut-turut.

3. Perusahaan yang telah diaudit oleh Akuntan Publik. 
4. Laporan keuangan menyajikan mata uang rupiah dalam pelaporan keuangan.

Perusahaan yang tidak mengalami kerugian selama periode 2016-2018.

Berdasarkan kriteria tersebut, diperoleh sampel sebanyak 24 perusahaan. Sampel dari penelitian ini adalah:

Tabel 1

Daftar Sampel Perusahaan

\begin{tabular}{|c|c|c|c|}
\hline No. & KODE & PERUSARAAN & SUB SEKTOR \\
\hline 1 & ADES & FI Akasba Wira Intenuticasl Tbk & Kosmetik dan Kumah Tangera \\
\hline 2 & BUDI & PT Budi Starth \& Swrectenar Thk & Matanin das Minumin \\
\hline 3 & CEKA & PT Wilnar Cahaya lndonesia Ttr & Makanan dan Manminan \\
\hline 4 & CINT & PT Chìtose Internasional Thk & Peralatan Renant Tagefa \\
\hline 5 & DLTA & PT Delia Djakanta ThE & Makanan din Mamman \\
\hline 6 & DVIA & PT Daryz-Varia Lataraiaria Tht & Fanati \\
\hline 7 & GGEM & PT Gudang Garaun Tk & Rekent \\
\hline 8 & HMSP & TT HM Sampeems Th & Rekak \\
\hline 9 & ICBP & PT Indofsed CBD Stkier Makanur THk & Makanan dan Minmman \\
\hline 10 & INDF & TT Indofoced Suknes Makimur Ttk & Matanan dan Minuman \\
\hline 11 & KINO & PT Kino Indonesia Ttk & Kosmetie dun Rumah Taggsa \\
\hline 12 & $\mathrm{KL} \mathrm{BF}$ & PT Kallhe Farm Thi & Farmalí \\
\hline 13 & MESK & DT Mardk THK & Farmensi \\
\hline 14 & MLB1 & PT Malti Biresng Indanesis Ttk & Makanan dun Mranman \\
\hline 15 & MYOR & FT Msyoen Indah Ttk & Makanan dan Minuman \\
\hline 15 & PYFA & PT Pyridem Fanea Tk & Fameas \\
\hline 17 & ROM & FT Nigpon lodosan Corpindo The & Matanin dan Minmmin \\
\hline 18 & SKLI & PT Strar laut Te & Makaman den Mamman \\
\hline 19 & SITP & Pr Siantax Jep Ttk & Makanan dan Mauman \\
\hline 20 & TCID & PT Mandmin ladsueia THK & Keswetili dun Kumah Tungsa \\
\hline 31 & TSPC & PT Trape San Padifi: Thi & Farmani \\
\hline 22 & पLT & TT then faya ME Istustry Thk & Makanan dan MSimuman \\
\hline 23 & UNVE & YT Uniliever Indenesis Thk & Kermertik dun Kumah Tangßa \\
\hline 24 & WIM & pT Wismilak Inti Makimir Ttk & Rokat \\
\hline
\end{tabular}

Teknik Analisa Data

\section{Analisis Pengujian Regresi Logistik}

Regresi logistik digunakan untuk menguji apakah variabel profitabilitas, ukuran perusahaan, umur perusahaan, opini auditor, dan struktur kepemilikan berpengaruh terhadap ketepatan waktu pelaporan keuangan. Model regresi logistik yang digunakan untuk menguji hipotesis sebagai berikut:

Ln $(\mathrm{KW} / \mathbf{1}-\mathrm{KW})=\alpha+\beta_{1}$ ROA $+\beta_{2} \mathrm{SIZE}+\beta_{3} \mathrm{AGE}$ $+\beta_{4}$ OPINI + $\beta_{5}$ STRUKTUR + DER + e Keterangan:

Ln $(\mathrm{KW} / 1-\mathrm{KW})=\quad$ Ketepatan Waktu

Pelaporan Keuangan

$\begin{array}{llll}\mathrm{A} & = & & \text { Konstanta } \\ \beta_{1}-\beta_{5}= & & \text { Koefisien regresi } \\ \text { ROA = } & & \text { Return on Asset } \\ \text { SIZE = } & & \text { Ukuran perusahaan } \\ \text { AGE = } & & \text { Umur perusahaan } \\ \text { OPINI = } & & \text { Opini Auditor } \\ \text { STRUKTUR }= & \text { Struktur Kepemilikan } \\ \text { LEVERAGE }= & \text { Debt to Equity Ratio } \\ \text { e } & = & \text { Error }\end{array}$

Beberapa hal yang perlu diperhatikan dalam uji koefisien regresi yaitu:

1. Tingkat signifikansi $(\alpha)$ yang digunakan sebesar $5 \%$.

2. Kriteria penerimaan dan penolakan hipotesis didasarkan pada signifikansi p-value (probabilitas value). Jika $p$-value $>\alpha$, maka hipotesis alternatif ditolak, sebaliknya jika $p$ value $<\alpha$, maka hipotesis alternatif diterima.

\section{Model Summary ( $\left.\mathbf{R}^{2}\right)$}

Model summary dalam regresi logistik sama dengan pengujian $\mathrm{R}^{2}$ pada persamaan regresi linier. Tujuan dari model summary adalah untuk mengetahui seberapa besar kombinasi variabel independen yang terdiri dari profitabilitas, ukuran perusahaan, umur perusahaan, opini auditor, dan struktur kepemilikan mampu menjelaskan variabel dependen yaitu ketepatan waktu pelaporan keuangan.

\section{Koefisien Regresi}

Koefisien regresi diuji untuk mengetahui seberapa besar pengaruh dari masing-masing variabel independen (bebas) terhadap variabel dependen (terikat). Koefisien regresi dapat ditentukan dengan menggunakan wald statistic dan nilai probabilitas (sig) dibandingkan dengan $\alpha$. Cara menentukan penolakan atau penerimaan Ho didasarkan pada tingkat signifikan $(\alpha)$ 5\% dengan kriteria sebagai berikut:

1. Apabila asymptotic significanse $>\alpha$, maka Ho diterima. Hal ini berarti $\mathrm{Ha}$ ditolak atau hipotesis yang menyatakan variabel bebas berpengaruh terhadap variabel terikat ditolak.

2. Apabila asymptotic significanse $<\alpha$, maka Ho ditolak. Hal ini berarti $\mathrm{Ha}$ diterima atau hipotesis yang menyatakan variabel bebas berpengaruh tehadap variabel terikat diterima. berikut:

Pengujian dilakukan dengan cara sebagai

1. Pengujian secara parsial

Pengujian secara parsial dilakukan untuk menguji pengaruh masing-masing variabel terhadap ketepatan waktu pelaporan keuangan.

2. Pengujian secara simultan

Pengujian secara simultan dilakukan untuk menguji pengaruh semua variabel terhadap ketepatan waktu pelaporan keuangan.

\section{HASIL DAN PEMBAHASAN}

\section{Hasil Analisis Pengujian Regresi Logistik}

1. Menilai Kelayakan Model Regresi (Goodness of Fit Test)

Berdasarkan tabel 2 menunjukkan bahwa nilai Hosmer and Lemeshow sebesar 12,694 dengan probabilitas signifikansi $0,123(0,123>0,05)$. Dengan demikian Ho diterima, sehingga dapat disimpulkan bahwa pada model regresi logistik yang digunakan telah memenuhi kecukupan data (fit).

\section{Tabel 2}

\section{Hosmer and Lemeshow Test}

\begin{tabular}{|c|c|c|c|}
\hline Step & Chi-square & df & Sig. \\
\hline 1 & 12.694 & 8 & .123 \\
\hline
\end{tabular}

Sumber: Output SPSS, 2021.

2. Menilai Keseluruhan Model (Overall Model Fit Test)

Langkah selanjutnya adalah menguji keseluruhan model regresi (overall model fit). Pengujian menilai keseluruhan model dilakukan dengan membandingkan nilai antara $-2 \quad$ Log Likelihood (-2LL) pada awal (Block Number $=0$ ) dengan nilai -2 Log Likelihood (-2LL) pada akhir (Block Number $=1$ ). Nilai -2 Log Likelihood Block 0: Beginning Block adalah 36,317 dan nilai -2 Log 
Likelihood Block 1: Method = Enter adalah 33,994. Hal ini menunjukkan terjadinya penurunan antara nilai -2 Log Likelihood Block 0 dan nilai -2 Likelihood Block 1 sebesar 36,317 - 33,994 = 2,323 penurunan nilai -2 Log Likelihood ini menunjukkan

\section{Model Summary}

\begin{tabular}{rr|r|r} 
Step & -2 Log likelihood & $\begin{array}{c}\text { Cox \& Snell R } \\
\text { Square }\end{array}$ & $\begin{array}{c}\text { Nagelkerke R } \\
\text { Square }\end{array}$ \\
\hline 1 & $33.994^{\mathrm{a}}$ & .032 & .080 \\
\hline
\end{tabular}

a. Estimation terminated at iteration number 7 because

parameter estimates changed by less than ,001.

regresi yang lebih baik dengan kata lain model yang dihipotesiskan fit dengan data. Hasil pengujian model fit dapat dilihat pada tabel 3 .

Tabel 3

Overall Model Fit Test Blok 0 : Beginning Block Iteration History ${ }^{\mathrm{a}, \mathrm{b}, \mathrm{c}}$

\begin{tabular}{llr|r} 
& & -2 Log likelihood & $\begin{array}{c}\text { Coefficients } \\
\text { Constant }\end{array}$ \\
\hline Iteration & & 40.894 & 1.722 \\
\cline { 2 - 4 } & 1 & 36.590 & 2.361 \\
\cline { 2 - 4 } & 2 & 36.319 & 2.574 \\
\cline { 2 - 4 } & 3 & 36.317 & 2.595 \\
\cline { 2 - 4 } & 4 & 36.317 & 2.595 \\
\hline
\end{tabular}

a. Constant is included in the model.

b. Initial -2 Log Likelihood: 36,317

c. Estimation terminated at iteration number 5 because parameter estimates changed by less than, 001 . Sumber: Output SPSS, 2021.

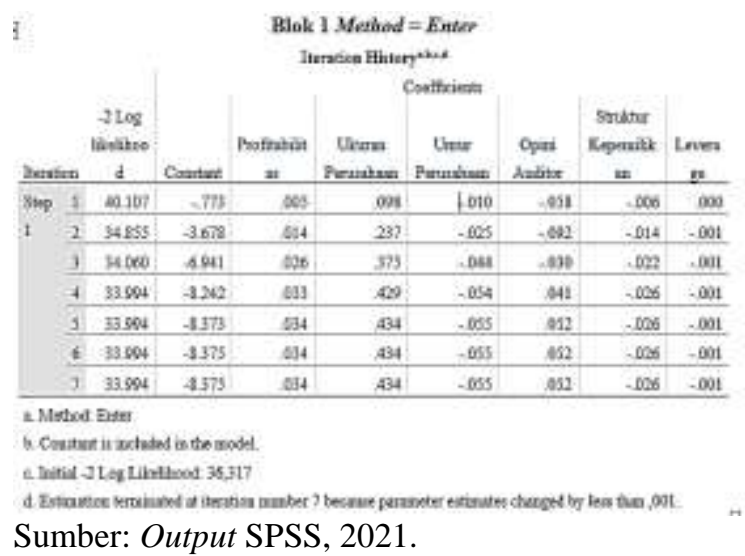

Koefisien Determinasi (Nagelkerke's $R$ Squere)

Model summary dalam regresi logistik sama dengan pengujian $\mathrm{R}^{2}$ pada persamaan regresi linier. Tujuan dari model summary adalah untuk mengetahui seberapa besar kombinasi variabel independen yang terdiri dari profitabilitas, ukuran perusahaan, umur perusahaan, opini auditor, struktur kepemilikan, dan leverage mampu menjelaskan variabel dependen yaitu ketepatan waktu pelaporan keuangan.

Berdasarkan hasil pengujian yang dilakukan pada nilai Nagelkerke's $R$ Squere adalah sebesar 0,080 yang berarti variabel independen yaitu profitabilitas, ukuran peusahaan, umur perusahaan, opini auditor, struktur kepemilikan, dan leverage mampu menjelaskan variasi dari variabel dependen yaitu ketepatan waktu pelaporan keuangan sebesar $8 \%$ dan sisanya $92 \%$ dijelaskan oleh faktor-faktor lainnya diluar model penelitian yang dilakukan. Hasil dari Nagelkerke's $R$ Squere dapat dilihat pada tabel 4.

\section{Tabel 4}

Sumber: Output SPSS, 2021

Hasil Uji Koefisien Regresi

Tahap akhir adalah menguji koefisien regresi, dimana hasilnya dapat dilihat pada tabel 5. Tabel tersebut menunjukkan hasil pengujian dengan regresi logistik pada tingkat signifikan 5\% dari pengujian persamaan regresi logistik tersebut, maka diperoleh model regresi sebagai berikut:

$$
\begin{gathered}
\mathrm{Ln}(\mathrm{KW} / 1-\mathrm{KW})=\alpha+\beta_{1} \mathrm{ROA}+\beta_{2} \mathrm{SIZE}+\beta_{3} \mathrm{AGE}+ \\
\beta_{4} \mathrm{OPINI}+\beta_{5} \mathrm{STRUKTUR}+\beta 6 \mathrm{LEVERAGE}+\mathrm{e} \\
\mathrm{Ln}(\mathrm{KW} / 1-\mathrm{KW})=\quad-8.375+0.034 \mathrm{ROA}+ \\
0.434 \mathrm{SIZE}-0.055 \mathrm{AGE}+0.052 \mathrm{OPINI}- \\
0.026 \mathrm{STRUKTUR}-0,001 \mathrm{LEVERAGE}+\mathrm{e}
\end{gathered}
$$

Tabel 5

\section{Koefisien Regresi Logistik}

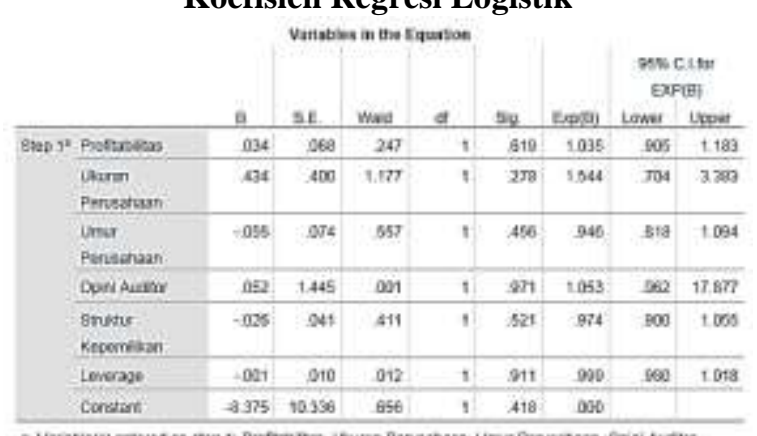

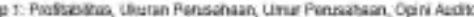
aruar Kegentisum, Lewerage

Sumber: Outpu SPSS, 2021

Nilai dari konstanta sebesar -8.375 menunjukkan bahwa ketika semua variabel $\mathrm{X}$ yaitu, profitabilitas, ukuran perusahaan, umur perusahaan, opini auditor, struktur kepemilikan, dan leverage bernilai 0 , maka variabel $\mathrm{Y}$ yaitu ketepatan waktu memiliki probabilitas menurun sebesar -8.375 .

1. Nilai koefisien regresi $\beta 10,034$ menunjukkan bahwa ketika profitabilitas bernilai 1 sedangkan ukuran perusahaan, umur perusahaan, opini auditor, struktur kepemilikan, dan leverage bernilai 0, maka variabel $\mathrm{Y}$ yaitu ketepatan 
waktu memiliki probabilitas meningkat sebesar 0,034 .

2. Nilai koefisien regresi $\beta 20,434$ menunjukkan bahwa ketika ukuran perusahaan bernilai 1 sedangkan profitabilitas, umur perusahaan, opini auditor, struktur kepemilikan, dan leverage bernilai 0 , maka variabel $\mathrm{Y}$ yaitu ketepatan waktu memiliki probabilitas meningkat sebesar 0,434 .

3. Nilai koefisien regresi $\beta 3-0,055$ menunjukkan bahwa ketika umur perusahaan bernilai 1 sedangkan profitabilitas, ukuran perusahaan, opini auditor, struktur kepemilikan, dan leverage bernilai 0 , maka variabel $\mathrm{Y}$ yaitu ketepatan waktu memiliki probabilitas menurun sebesar $-0,055$.

4. Nilai koefisien regresi $\beta 40,052$ menunjukkan bahwa ketika opini auditor bernilai 1 sedangkan profitabilitas, ukuran perusahaan, umur perusahaan, struktur kepemilikan, dan leverage bernilai 0 , maka variabel $\mathrm{Y}$ yaitu ketepatan waktu memiliki probabilitas meningkat sebesar 0,052 .

5. Nilai koefisien regresi $\beta 5-0,026$ menunjukkan bahwa ketika struktur kepemilikan bernilai 1 sedangkan profitabilitas, ukuran perusahaan, umur perusahaan, opini auditor, dan leverage bernilai 0 , maka variabel $\mathrm{Y}$ yaitu ketepatan waktu memiliki probabilitas menurun sebesar 0,026 .

6. Nilai koefisien regresi $\beta 6-0.001$ menunjukkan bahwa ketika leverage bernilai 1 sedangkan profitabilitas, ukuran perusahaan, umur perusahaan, opini auditor, dan struktur kepemilikan bernilai 0, maka variabel $\mathrm{Y}$ yaitu ketepatan waktu memiliki probabilitas menurun sebesar -0.001 .

\section{Hasil Uji Hipotesis}

Uji $\mathrm{T}$ dilakukan dalam penelitian ini untuk menguji pengaruh secara individual antara profitabilitas, opini audit, ukuran perusahaan, umur perusahaan, struktur kepemilikan, dan leverage terhadap ketepatan waktu. Pengujian ini dilakukan dengan membandingkan antara tingkat signifikasi (sig.) dengan tingkat kesalahan $(\alpha)=5 \%(0,05)$.

Berdasarkan tabel 5 diatas, maka di dapat hasil sebagai berikut:

H1 : Profitabilitas berpengaruh positif terhadap ketepatan waktu pelaporan keuangan.

Variabel profitabilitas yang diukur menggunakan Return on Assets (ROA) menunjukkan nilai koefisien positif sebesar 0,034 dengan nilai signifikansi sebesar 0,619 diatas tingkat signifikan $0,05(5 \%)$, Sehingga dapat disimpulkan bahwa profitabilitas tidak berpengaruh terhadap ketepatan waktu pelaporan keuangan. Maka H1 yang menyatakan bahwa: "profitabilitas berpengaruh positif terhadap ketepatan waktu pelaporan keuangan" ditolak.
H2 : Ukuran Perusahaan berpengaruh positif terhadap ketepatan waktu pelaporan keuangan.

Variabel ukuran perusahaan yang diukur dengan Ln (Total Assets) menunjukkan nilai koefisien positif sebesar 0,434 dengan nilai signifikansi sebesar 0,278 diatas tingkat signifikan $0,05(5 \%)$. Sehingga dapat disimpulkan bahwa ukuran perusahaan tidak berpengaruh terhadap ketepatan waktu pelaporan keuangan. Maka H2 yang menyatakan bahwa: "ukuran perusahaan berpengaruh positif terhadap ketepatan waktu pelaporan keuangan" ditolak.

H3 : Umur perusahaan berpengaruh positif terhadap ketepatan waktu pelaporan keuangan

Variabel umur perusahaan yang diukur dengan tanggal listed-nya perusahaan dipasar modal menunjukkan nilai koefisien negarif sebesar $-0,055$ dengan nilai signifikansi sebesar 0,456 diatas tingkat signifikan $0,05(5 \%)$. Sehingga dapat disimpulkan bahwa umur perusahaan tidak berpengaruh terhadap ketepatan waktu pelaporan keuangan. Maka H3 yang menyatakan bahwa: "umur perusahaan berpengaruh positif terhadap ketepatan waktu pelaporan keuangan" ditolak.

H4 : Opini auditor berpengaruh positif terhadap ketepatan waktu pelaporan keuangan

Variabel opini auditor yang diukur dengan variabel dummy, dimana kategori perusahaan yang mendapatkan opini wajar tanpa pengecualian diberi kategori 1 dan perusahaan yang mendapatkan opini selain wajar tanpa pengecualian diberi kategori 0 . Menunjukkan nilai koefisien positif sebesar 0,052 dengan nilai signifikansi sebesar 0,971 diatas tingkat signifikan $0,05(5 \%)$. Sehingga dapat disimpulkan bahwa opini auditor tidak berpengaruh terhadap ketepatan waktu pelaporan keuangan. Maka H4 yang menyatakan bahwa: "opini auditor berpengaruh positif terhadap ketepatan waktu pelaporan keuangan" ditolak.

H5 : Struktur kepemilikan berpengaruh positif terhadap ketepatan waktu pelaporan keuangan.

Variabel struktur kepemilikan yang diukur dengan melihat dari seberapa besar saham yang dimiliki oleh pihak luar pada perusahaan go public menunjukkan nilai koefisien negatif sebesar $-0,026$ dengan nilai signifikansi sebesar 0,521 dibawah tingkat signifikan $0,05 \quad(5 \%)$. Sehingga dapat disimpulkan bahwa struktur kepemilikan berpengaruh negatif terhadap ketepatan waktu pelaporan keuangan. Maka H5 yang menyatakan bahwa: "struktur kepemilikan berpengaruh positif terhadap ketepatan waktu pelaporan keuangan" ditolak.

H6 : Leverage berpengaruh positif terhadap ketepatan waktu pelaporan keuangan.

Variabel leverage yang diukur menggunakan debt to equity ratio menunjukkan nilai koefisien negatif sebesar $-0,001$ dengan nilai signifikansi sebesar 0,911 diatas tingkat signifikan 0,05 (5\%). Sehingga dapat disimpulkan bahwa leverage tidak 
berpengaruh terhadap ketepatan waktu pelaporan keuangan. Maka H6 yang menyatakan bahwa: "leverage berpengaruh positif terhadap ketepatan waktu pelaporan keuangan" ditolak.

Berdasarkan hasil analisis logistic reggression diketahui bahwa secara simultan variabel Profitabilitas, Ukuran Perusahaan, Umur Perusahaan, Opini Auditor, Struktur Kepemilikan, dan Leverage berpengaruh terhadap ketepatan waktu pelaporan keuangan pada perusahaan consumer goods di BEI. Hal ini dapat dilihat bahwa nilai -2 log likelihood (33.994) > F tabel $(2,23)$ atau sig. $0,000<0,05$. Besarnya pengaruh variabel Profitabilitas, Ukuran Perusahaan, Umur Perusahaan, Opini Auditor, Struktur Kepemilikan, dan Debt to Equity Ratio dapat dilihat dari nilai Nagelkerke $R$ Square (R2) sebesar 0.080, berarti variabel Profitabilitas, Ukuran Perusahaan, Umur Perusahaan, Opini Auditor, Struktur Kepemilikan, dan Debt to Equity Ratio mampu menjelaskan ketepatan waktu pelaporan keuangan pada perusahaan consumer goods di BEI sebesar $8 \%$.

\section{Pembahasan Hasil Penelitian}

1. Pengaruh profitabilitas terhadap ketepatan waktu pelaporan keuangan

Hasil penelitian pengaruh profitabilitas terhadap ketepatan waktu pelaporan keuangan menunjukan bahwa profitabilitas tidak berpengaruh terhadap ketepatan waktu pelaporan keuangan, sehingga hipotesis pertama (H1) dalam penelitian ini ditolak. Hal ini terlihat dari nilai signifikansinya melalui uji regresi logistik yang menunjukkan angka diatas 0,05 (5\%) yaitu 0,619. Dengan demikian, pada penelitian ini hipotesis pertama yang mengatakan bahwa profitabilitas berpengaruh positif terhadap ketepatan waktu pelaporan keuangan tidak diterima/ditolak

2. Pengaruh ukuran perusahaan terhadap ketepatan waktu pelaporan keuangan

Hasil penelitian pengaruh ukuran perusahaan terhadap ketepatan waktu pelaporan keuangan menunjukan bahwa ukuran perusahaan tidak berpengaruh terhadap ketepatan waktu pelaporan keuangan, sehingga hipotesis kedua (H2) dalam penelitian ini ditolak. Hal ini terlihat dari nilai signifikansinya melalui uji regresi logistik yang menunjukkan angka diatas $0,05(5 \%)$ yaitu 0,278 . Dengan demikian, pada penelitian ini hipotesis kedua yang mengatakan bahwa ukuran perusahaan berpengaruh positif terhadap ketepatan waktu pelaporan keuangan tidak diterima/ditolak.

3. Pengaruh umur perusahaan terhadap ketepatan waktu pelaporan keuangan

Hasil penelitian pengaruh umur perusahaan terhadap ketepatan waktu pelaporan keuangan menunjukkan bahwa umur perusahaan tidak berpengaruh terhadap ketepatan waktu pelaporan keuangan, sehingga hipotesis ketiga (H3) dalam penelitian ini ditolak. Hal ini terlihat dari nilai signifikansinya melalui uji regresi logistik yang menunjukkan angka diatas $0,05(5 \%)$ yaitu 0,456 . Dengan demikian, pada penelitian ini hipotesis ketiga yang mengatakan bahwa umur perusahaan berpengaruh positif terhadap ketepatan waktu pelaporan keuangan tidak diterima/ditolak.

4. Pengaruh opini auditor terhadap ketepatan waktu pelaporan keuangan

Hasil penelitian pengaruh opini auditor terhadap ketepatan waktu pelaporan keuangan menunjukkan bahwa opini auditor tidak berpengaruh terhadap ketepatan waktu pelaporan keuangan, sehingga hipotesis keempat $(\mathrm{H} 4)$ dalam penelitian ini ditolak. Hal ini terlihat dari nilai signifikansinya melalui uji regresi logistik yang menunjukkan angka diatas $0,05(5 \%)$ yaitu 0,971. Dengan demikian, pada penelitian ini hipotesis keempat yang mengatakan bahwa opini auditor berpengaruh positif terhadap ketepatan waktu pelaporan keuangan tidak diterima/ditolak.

5. Pengaruh struktur kepemilikan terhadap ketepatan waktu pelaporan keuangan

Hasil penelitian pengaruh struktur kepemilikan terhadap ketepatan waktu pelaporan keuangan menunjukkan bahwa struktur kepemilikan tidak berpengaruh terhadap ketepatan waktu pelaporan keuangan, sehingga hipotesis kelima (H5) dalam penelitian ini ditolak. Hal ini terlihat dari nilai signifikansinya melalui uji regresi logistik yang menunjukkan angka diatas $0,05(5 \%)$ yaitu 0,521 . Dengan demikian, pada penelitian ini hipotesis kelima yang mengatakan bahwa struktur kepemilikan berpengaruh positif terhadap ketepatan waktu pelaporan keuangan tidak diterima/ditolak.

6. Pengaruh leverage terhadap ketepatan waktu pelaporan keuangan

Hasil penelitian pengaruh leverage terhadap ketepatan waktu pelaporan keuangan menunjukkan bahwa leverage tidak berpengaruh terhadap ketepatan waktu pelaporan keuangan, sehingga hipotesis keenam (H6) dalam penelitian ini ditolak. Hal ini terlihat dari nilai signifikansinya melalui uji regresi logistik yang menunjukkan angka diatas 0,05 (5\%) yaitu 0,911 . Dengan demikian, pada penelitian ini hipotesis keenam yang mengatakan bahwa leverage berpengaruh positif terhadap ketepatan waktu pelaporan keuangan tidak diterima/ditolak.

\section{KESIMPULAN DAN SARAN}

\section{Simpulan}

Berdasarkan hasil penelitian mengenai faktor-faktor yang mempengaruhi ketepatan waktu 
pelaporan keuangan, dapat disimpulkan sebagai berikut:

1. Hasil penelitian dan pembahasan diketahui bahwa secara parsial profitabilitas tidak berpengaruh terhadap ketepatan waktu pelaporan keuangan pada perusahaan consumer goods di BEI.

2. Hasil penelitian dan pembahasan diketahui bahwa secara parsial ukuran perusahaan tidak berpengaruh terhadap ketepatan waktu pelaporan keuangan pada perusahaan consumer goods di BEI.

3. Hasil penelitian dan pembahasan diketahui bahwa secara parsial umur perusahaan tidak berpengaruh terhadap ketepatan waktu pelaporan keuangan pada perusahaan consumer goods di BEI.

4. Hasil penelitian dan pembahasan diketahui bahwa secara parsial opini auditor tidak berpengaruh terhadap ketepatan waktu pelaporan keuangan pada perusahaan consumer goods di BEI.

5. Hasil penelitian dan pembahasan diketahui bahwa secara parsial struktur kepemilikan tidak berpengaruh terhadap ketepatan waktu pelaporan keuangan pada perusahaan consumer goods di BEI.

6. Hasil penelitian dan pembahasan diketahui bahwa secara parsial leverage tidak berpengaruh terhadap ketepatan waktu pelaporan keuangan pada perusahaan consumer goods di BEI.

7. Hasil penelitian dan pembahasan diketahui bahwa secara simultan variabel profitabilitas, ukuran perusahaan, umur perusahaan, opini auditor, struktur kepemilikan, dan leverage berpengaruh terhadap ketepatan waktu pelaporan keuangan pada perusahaan consumer goods di BEI.

\section{Saran}

Saran untuk penelitian mendatang adalah:

1. Bagi manajemen perusahaan sebaiknya menganalisis ketepatan waktu pelaporan keuangan perusahaan untuk mengantisipasi terjadinya sanksi atau teguran dari Otoritas Jasa Keuangan (OJK) jika perusahaan mengabaikan hal tersebut. Ketepatan waktu pelaporan keuangan merupakan kondisi dimana perusahaan memiliki kepatuhan dalam melaporkan laporan keuangannya secara tepat waktu sesuai aturan yang telah ditetapkan.

2. Bagi pihak perusahaan sebaiknya berusaha mempertahankan kelangsungan hidup perusahaannya agar mampu bertahan dengan pesaing yang lain yang lebih kuat karena hal ini dapat menjadi pertimbangan bisnis bagi investor untuk menanamkan sahamnya karena investor melihat waktu perusahaan tersebut memiliki umur yang sudah matang dan memiliki kemampuan yang baik dalam bisnis seiring dengan pengalaman yang dimilikinya.

3. Bagi peneliti berikutnya untuk memperluas penelitian dengan menambah variabel penelitian, objek penelitian dari seluruh perusahaan yang terdaftar di Bursa Efek Indonesia dan periode pengamatan yang lebih panjang sehingga hasil yang diperoleh akan lebih dapat digeneralisasi dan akan menggambarkan kondisi sesungguhnya selama jangka panjang.

\section{DAFTAR PUSTAKA}

Agoes, S. 2012. Auditing petunjuk praktis pemeriksaan akuntan oleh akuntan publik. Jakarta: Salemba Empat.

Arens, AA, Elder, RJ, Beasly, MS. 2008. Auditing dan Jasa Assurance. Jilid I. Jakarta: PT. Gelora Aksara Pratama.

Anggreani, Retno Ajeng dan Endang Dwi Retnani. 2018. Faktor-faktor yang Mempengaruhi Ketepatan Waktu Penyajian Laporan Keuangan. Jurnal Ilmu dan Riset Akuntansi. Vol.7 No.1 Hal 1-20. (http://jurnalmahasiswa.stiesia.ac.id/index.p hp/jira/article/download/35/28).

Astuti, Widia dan Teguh Erawati. 2018. Pengaruh Profitabilitas, Umur Perusahaan dan Ukuran Perusahaan Terhadap Ketepatan Waktu Penyampaian Laporan Keuangan Perusahaan (Studi Pada Perusahaan Manufaktur Yang Terdaftar di Bursa Efek Indonesia Tahun 2012-2016). Vol.26 No.2 Juli, 2018, Hal 144-157. (https://doi.org/10.32477/jkb.v26i2.108).

Budiyanto, Sarwono dan Elma Muncar Aditya. 2015. Faktor-Faktor yang Mempengaruhi Ketepatan Waktu Pelaporan Keuangan (Studi Empiris Perusahaan Food and Beverages Periode 2010-2012). Vol.10 No.1 Juni, Hal 77-87.

(http://www.ejournal.stiepena.ac.id/index.ph $\mathrm{p} / \mathrm{fe} /$ article/viewFile/74/71).

Choiruddin. 2015. Analisis Faktor-Faktor Yang Mempengaruhi Ketepatan waktu Pelaporan Keuangan (Studi Empiris Pada Perusahaan Manufaktur Yang Terdaftar Di Bursa Efek Indonesia Periode 2009-2013). Jurnal Akuntansi Politeknik Sekayu (ACSY). Vol.II No.1 Hal 41-56. (http://download.garuda.ristekdikti.go.id/arti cle.php? article $=809416 \&$ val=13212\&title).

Dewayani, Mega Arista, Moh. Al Amin, dan Veni Soraya Dewi. 2017. Analisis Faktor-Faktor yang Mempengaruhi Ketepatan Waktu Pelaporan Keuangan (Studi Empiris Pada Perusahaan Manufaktur yang 
Terdaftar di Bursa Efek Indonesia Periode 2011-2016). University Research Colloquium, Hal 441-458. (http://journal.ummgl.ac.id/index.php/urecol /article/view/1567/784).

Dwiyanti, Rini. 2010. Analisis Faktor-faktor yang Mempengaruhi Ketepatan Waktu Pelaporan Keuangan (Studi Empiris pada Perusahaan Manufaktur yang Terdaftar di Bursa Efek Indonesia Tahun 2005-2007). Skripsi. Semarang: Fakultas Ekonomi Universitas Diponegoro. (http://eprints.undip.ac.id/22634/1/Skripsi_ Rini_Dwiyantipdf.pdf).

Fahmi, Irham. 2011. Analisis Kinerja Keuangan. Bandung: Alfabeta.

Ghozali, Imam. 2016. Aplikasi Analisis Multivariate Dengan Program IBM SPSS 23, edisi 8. Semarang: Badan Penerbit Undip.

Hanafi, Mamduh M dan Abdul Halim. 2016. Analisis Laporan Keuangan. Edisi Kelima. Yogyakarta: UPP STIM YKPN.

Herry. 2012. Memahami Laporan Keuangan. Jakarta: PT Bumi Aksara.

Hijriyah, Andi Gina. 2018. Faktor-Faktor yang Mempengaruhi Ketepatan Waktu Pelaporan Keuangan Pada Perusahaan Perbankan yang Terdaftar di Bursa Efek Indonesia. Skripsi. Banjarmasin: STIE Indonesia Banjarmasin.

https://investasi.kontan.co.id/news/masih-ada-107emiten-belum-menyampaikan- laporankeuangan-semester-i-2019.

https://www.edusaham.com/2019/02/cara-mencaridata-kepemilikan-manajerial- sahammanajerial.html.

https://www.ojk.go.id/id/kanal/pasarmodal/regulasi/undangundang/Documents/Pages/undang-undangnomor-8-tahun-1995-tentang-pasarmodal/UU\%20Nomor\%208\%20Tahun\%201 995\%20(official).pdf

Imaniar, Fitrah Qulukhil. 2016. Faktor-Faktor yang Mempengaruhi Ketepatan Waktu Pelaporan Keuangan Perusahaan. Jurnal Ilmu dan Riset Akuntansi. Vol.5 No 6 Juni 2016. (https://docplayer.info/48732018-Faktorfaktor-yang-mempengaruhi-ketepatanwaktu-pelaporan-keuanganperusahaan.html).
Juwita. 2010. Analisis Faktor-Faktor yang Mempengaruhi Ketepatan Waktu Pelaporan Keuangan Perusahaan Manufaktur yang Listing di Bursa Efek Indonesia (BEI). Skripsi. Pekanbaru: Fakultas Ekonomi dan Ilmu Sosial Universitas Islam Negeri Sultan Syarif Kasim Riau. (http://repository.uinsuska.ac.id/11000/1/2010_2010287AKN.pdf).

Kartikahadi, Hans, Rosita Uli Sinaga, Merliyana Syamsul, dan Sylvia Veronica Siregar. 2012. Akuntansi Keuangan berdasarkan SAK berbasis IFRS. Jakarta: Salemba Empat.

Kasmir. 2018. Analisis Laporan Keuangan. Edisi 8. Jakarta: PT RajaGrafindo Persada.

Luqiana, Lulu Cahyaningsih, dan Djusnimar Zultilisna. 2018. Analisis Faktor-Faktor yang Meningkatkan Ketepatan Waktu Penyampaian Laporan Keuangan. Vol.3 No.3. Agustus. Hal 220-232. (http://akrabjuara.com/index.php/akrabjuara/ article/view/310/242).

Ningtyas, S. A. S., dan Engelwati Gani. 2014. Analisis Faktor-Faktor yang Mempengaruhi Ketepatan Waktu Pelaporan Keuangan Pada Perusahaan Manufaktur yang Terdaftar di Bursa Efek Indonesia. Tesis. Jakarta. Fakultas Ekonomi dan Bisnis BINUS. (http://eprints.binus.ac.id/31310).

Nugraha, Reza, dan Dini Wahjoe Hapsari. 2015. Pengaruh leverage, Profitabilitas, Ukuran Perusahaan Terhadap Ketepatan Waktu Penyampaian Pelaporan Keuangan (Studi empiris pada perusahaan disektor Jasa yang terdaftar di Bursa Efek Indonesia periode 2010-2013). Vol. 2 No.1 April. Hal 166. (https://core.ac.uk/download/pdf/299900138 .pdf)

Nuro, Rizqi Janna, Sochib, dan Muhammad Mudhofar. 2019. Pengaruh Profitabilitas, Kepemilikan Publik, Dan Opini Auditor Terhadap Ketepatan Waktu Pelaporan Keuangan Pada Perusahaan Industri Barang Konsumsi Yang Terdaftar di BEI Periode 2013-2015. Vol.1 No.4. Juni. Hal 106-117. (http://jkm.stiewidyagamalumajang.ac.id/in dex.php/jra/article/download/177/138).

Prahesty, Siska. 2011. Analisis Faktor-Faktor yang Mempengaruhi Ketepatan Waktu Pelaporan Keuangan (Studi Empiris pada Perusahaan Food and Beverages di Bursa Efek 
Indonesia Periode 2004-2009. Skripsi. Semarang: Fakultas Ekonomi Universitas Diponegoro.

(http://eprints.undip.ac.id/26839/1/SKRIPSI _FULL_TEXT(r).pdf).

Putri, Alzena Wandha. 2018. Faktor-Faktor yang Mempengaruhi Ketepatan Waktu Penyampaian Laporan Keuangan (Studi Empiris Pada Laporan Keuangan Perusahaan Manufaktur yang Terdaftar di Bei tahun 2010-2016). Skripsi. Yogyakarta: Fakultas Ekonomi Universitas Islam Indonesia. (https://dspace.uii.ac.id/bitstream/handle/12 3456789/9527/SKRIPSI\%20Alzena\%20Wa ndha\%20Putri.pdf? sequence=1).

Pujiatmi dan Kun Ismawati. 2018. Faktor yang Mempengaruhi Ketepatan Waktu Pelaporan Keuangan. Vol.VII, No.1 Agustus, Hal 4376.

(http://www.jurnal.usahidsolo.ac.id/index.ph p/IAB/article/view/172/132,

Rahayu, Ratna Dwi Titi. 2017. Pengaruh Ukuran Perusahaan, Umur Perusahaan, Opini Auditor, Dan Kepemilikan Publik Terhadap Ketepatan Waktu Penyampaian Laporan Keuangan (Studi Empiris pada Perusahaan Manufaktur yang Terdaftar di BEI Periode 2011 - 2015). Skripsi. Fakultas Ekonomi. Universitas Negeri Yogyakarta. (https://eprints.uny.ac.id/50967/1/SKRIPSI_ RATNA\%20DWI\%20TITI\%20RAHAYU_ 15812147016.pdf).

Rahma, Anita Ade, Lusiana, dan Puput Indriani. 2019. Pengaruh Struktur Modal, Profitabilitas, dan Size Perusahaan Terhadap Ketepatan Waktu Pelaporan Keuangan Pada Perusahaan Manufaktur. Juli, Hal 210-220. (http://ejournal.lldikti10.id/index.php/benefi ta/article/view/3698/0).

Sanjaya, I.M.D.M dan N.G.P Wirawati. 2016. Analisis Faktor-Faktor yang Mempengaruhi Ketepatan Waktu Pelaporan Keuangan Pada Perusahaan Manufaktur yang Terdaftar di BEI. Vol.15.1 April, Hal 1726.(https://ojs.unud.ac.id/index.php/Akuntan si/article/view/15057).

Sari, Dian Retno. 2019. Faktor-Faktor yang Mempengaruhi Ketepatan Waktu Pelaporan Keuangan Pada Perusahaan Sub Sektor Perdagangan Eceran (Retail) yang Terdaftar di Bursa Efek Indonesia Periode 2014-2017. Skripsi. Banjarmasin: STIEI Indonesia Banjarmasin.

Sugiarto. 2009. Struktur Modal, Struktur Kepemilikan Perusahaan, Permasalahan
Keagenan dan Informasi Asimetri. Yogyakarta: Graha Ilmu.

Suherdi, Arief. 2018. Pengaruh Kompleksitas Operasi Perusahaan, Profitabilitas, dan Ukuran Perusahaan, Terhadap Ketepatan Waktu Pelaporan Keuangan (Timeliness Of Financial Reporting). Skripsi. Yogyakarta. Fakultas Ekonomi Universitas Islam Indonesia.

(https://dspace.uii.ac.id/bitstream/handle/12 3456789/10800/SKRIPSI\%20Arief\%20Suh erdi.pdf? sequence $=1 \&$ is Allowed $=y$ ).

Suryanto, Joko dan Indra Pahala. 2016. Analisa Faktor-Faktor Yang Berpengaruh Terhadap Ketepatan Waktu Pelaporan Keuangan (Studi Empiris Pada Perusahaan Otomotif Dan Komponen Dan Telekomunikasi Yang Terdaftar Di Bursa Efek Indonesia). Vol.11 No.2.

(http://journal.unj.ac.id/unj/index.php/wahan a-

akuntansi/article/download/889/80

1).

Ustman, Muhammad Ali. 2018. Analisis FaktorFaktor Ketepatan Waktu Penyampaian Laporan Keuangan Perusahaan Sektor Barang Konsumsi. Skripsi.

Yogyakarta: Fakultas Ekonomi Universitas Islam

Indonesia.(https://dspace.uii.ac.id/bitstream/ handle/123456789/8189/ANALISIS\%20F AKTOR-

FAKTOR\%20KETEPATAN\%20WAKTU $\%$ 20PENYAMPAIAN\%20LAPORAN\%20 KEUANGAN\%20PERUSAHAAN\%20SEK TOR\%20BARANG $\% 20 K O N S U M S I-$

14312172,\%20MUHAMMAD\%20ALI\%20 USTMAN.pdf?sequence $=1$ ).

Valentina, I Gst Ayu Putu Bunga, dan Gayatri. 2018. Pengaruh Profitabilitas, Ukuran

Perusahaan, Struktur Kepemilikan, Leverage, dan Umur Perusahaan Pada Ketepatan Waktu Pelaporan Keuangan. Vol.22 No.1, Januari Hal 572-594. (https://ojs.unud.ac.id/index.php/Akuntansi/ article/download/32650/2210)

Wahyuni, Nur. 2018. Pengaruh Profitabilitas, Likuiditas, Struktur Kepemilikan, dan Firm Size Terhadap Ketepatan Waktu Pelaporan Keuangan. Artikel Ilmiah. Surabaya: Sekolah Tinggi Ilmu Ekonomi Perbanas.

(http://eprints.perbanas.ac.id/3472/8/ARTIK EL\%20ILMIAH.pdf).

www.idx.co.id 
Yadika, B. 2019. Dua Sektor Saham Bakal Perkasa pada Tahun Politik. (https://www.liputan6.com/bisnis/read/3863 128/dua-sektor-saham-bakal-perkasa-padatahun-politik\#)

Yunita, Trisiana. 2017. Analisis Faktor-Faktor yang Mempengaruhi Ketepatan Waktu

Penyampaian Laporan Keuangan (Studi Empiris pada Perusahaan Manufaktur yang Terdaftar di BEI Periode 2012-2015). Skripsi. Yogyakarta: Fakultas Ekonomi Universitas Islam Indonesia. (https://dspace.uii.ac.id/bitstream/handle/12 3456789/9856/skripsi.pdf?seq uence $=15 \&$ is Allowed $=y$ ).

\section{PROFIL PENULIS}

H. Hasdi Suryadi, S.E, M.M, AK, CA, BKP, CPA. Dosen STIE Pancasetia Banjarmasin Program Studi Akuntansi. Jl. Yani Km. 5.5 Kecamatan Banjarmasin Selatan Kota Banjarmasin.

Email: hasdisuryadi@yahoo.com 